\title{
Common Sage (Salvia officinalis L.) Breeding Studies in Central Anatolian Climatic Conditions
}

\author{
Reyhan BAHTIYARCA BAĞDAT ${ }^{*}$, Nurettin ÇiNKAYA ${ }^{1}$, \\ Kadriye YÜKSEL DEMIRAY ${ }^{2}$, Çiğdem BOZDEMIR ${ }^{1}$, Emel ÇAKIR $^{3}$
}

\author{
${ }^{1}$ Central Research Institute for Field Crops, Şehit Cem Ersever Cad. No: 9/11 Yenimahalle, Ankara, Turkey \\ ${ }^{2}$ Western Mediterranean Agricultural Research Institute, Demircikara Mah. Paşa Kavakları Cad. No:11 Pk:35 \\ Antalya, Turkey \\ ${ }^{3}$ Directorate of Plant Protection Central Research Institute, Fatih Sultan Mehmet Bulvar1 No: 66, 06172, Ankara, \\ Turkey
}

Received: 28 April 2017 - Accepted: 03 June 2017

\begin{abstract}
Salvia officinalis L., Lamiaceae, known as Dalmatian Sage or common sage has been gaining popularity in food and drug industries worldwide, recently. Even the existence of many sage species on the World, the genus officinalis has medicinal common use. Indigestion and inflammation disorders, excessive sweating, including that associated with peri-menopause; relief of pressure spots that result from the use of a prosthesis; and as a flavoring for foods are the main areas where the plant is mainly consumed. Sage essential oil has also been employed as a fragrance in soaps and perfumes. Wide adaptability and non-selective climatic requirements of the plats made it possible to receive high biomass, and several harvests during the same plantation period. Present study was conducted in Ankara, during the successive two growing season of 2014 and 2016. Thirty-three spontaneous hybrid common sage lines (Salvia officinalis L.) were evaluated regarding their biomass production and essential oil characteristics employing 4 different standard sage cultivars and lines. Following yield parameters were recorded as; the plant height was ranged 50.3 to $97.5 \mathrm{~cm}$, canopy diameter was 36.0 to $95.0 \mathrm{~cm}$, fresh herb yield was changed 59.9 to $593.4 \mathrm{~g} /$ per plant, drug herb yield was 12.6 to $183.9 \mathrm{~g} / \mathrm{per}$ plant, drug leaf yield was 16.1 to $74.5 \mathrm{~g} / \mathrm{per}$ plant and the leaf ratio was around 53.42-67.01\%. The essential oil ratio was changed between 0.88 and $2.42 \%$. All the yield parameters of the lines were found statistically significant. $\alpha$-thujone, 1.8 cineole, borneol, camphor, $\beta$-thujone, camphene and viridiflorol were the main components. More than ten lines had less than $20 \%$ of $\alpha$-thujone. Phytophtora cryptogea was identified as devastating pathogen confirmed by molecular characterization.
\end{abstract}

Keywords: Common sage (Salvia officinalis L.), plant height, canopy width, drug herb yield, drug leaf yield, essential oil yield, $\alpha$-thujone, Phytophtora cryptogea

\section{INTRODUCTION}

Common sage or Dalmatian Sage (Salvia officinalis L.) belongs to Lamiaceae, an attractive cross pollinated perennial, growing up to 60-100 cm. It has a woody stems, grayish leaves, and blue to purplish flowers. Flowers are clustered by 4 to 8 groups at the end of the stems. Common sage has a long history of medicinal and culinary use [1]. More than 90 sage

*Corresponding Author E-mail: reyhanbagdat@yahoo.com

ISSN: $2148-6905$ online /C) 2017

DOI: $10.21448 /$ ijsm.377416 
(Salvia sp.) species are found in Anatolian flora of Turkey. Although Salvia officinalis is not originally from Turkey, it has been well adapted to Central Anatolian climatic conditions. Salvia officinalis and Salvia fruticosa are the main species having economic value due to the presence of terpenoids, tannins, bitter substances and essential oil contents (1.0- 2.5\%). Drugs collected from natural flora have resulted in the extinction of some Salvia species and has let to use of the undesired materials like Phlomis species in order to sage. Due to meet increased industrial demands, Turkey commonly import and re-import sage from Balkan countries in some years. New lines and cultivars having acceptable volatile oil contents should be bred; which will help in provision of high quality raw material for industrial use without depending on natural flora. There were limited studies on sage cultivation conducted under Central Anatolian conditions. Common sage has a wide adaptability and drought and cold resistance having high biomass production and regeneration ability. Present research aims to develop multiple clones or lines in common sage (S. officinalis L.) adaptable to Central Anatolian climatic conditions having high biomass and essential oil yield, with low thujone content. For this purpose, the preliminary yield experiment was established by the selection of single plants from a spontaneous hybrid sage plantation in Haymana Ikizce Research and Application Farm. The yield and quality parameters of prominent lines were recorded for further selections to establish yield experiments.

\section{MATERIAL and METHODS}

\subsection{Plant Material and Experimental}

Common sage (Salvia officinalis L.) is a highly cross-pollinated perennial having high biomass production which provides their cultivars two or more harvests in a plantation year. Single plants were selected from a spontaneous hybrid plantation in Haymana/Ikizce Research and Application Farm and rooted in perlite. 30 lines were evaluated in primarily yield experiment established by augmented design technique, using four different cultivars and lines from Swiss (CV Regula), Israel (population), Italy (USDA IP: 4620659) and Germany (population). Rooted lines were planted using $60 \times 40 \mathrm{~cm}$ raw spacing. Clonal line selection is being followed as a breeding method [2]. Ten single plants were evaluated according to following parameters; plant height $(\mathrm{cm})$, number of shoot (number), canopy width $(\mathrm{cm}), 90^{\circ}$ canopy width $(\mathrm{cm})$, fresh herb $(\mathrm{g})$, dry herb $(\mathrm{g})$, fresh leaf yield $(\mathrm{g})$ and dry leaf yield $(\mathrm{g})$, essential oil ratio $(\%)$ and components.

\subsection{Essential Oil Isolation}

Essential oils of the common sage lines were characterized by GC-MS in the Medicinal and Aromatic Plants Laboratory of Batı Akdeniz Agricultural Research Institute. The plant samples for essential oil analyses were taken from 9 plants representing each application. Fresh material was kept to dry 3 days in a $35^{\circ} \mathrm{C}$ incubator, inside paper lunch bags. Dry leaves $(100$ $\mathrm{g})$ were placed into a distillation apparatus with $2 \mathrm{~L}$ of distilled water and vapor distilled for 3 h. Steam distillation of MAPs were recommended by several previous studies for lavender and rosemary [3,4,5]. The GC/MS analysis was carried out with an Agilent 5975 GC-MS system. Innowax FSC column $(60 \mathrm{~m} \times 0.25 \mathrm{~mm}, 0.25 \mu \mathrm{m}$ film thickness) was used with helium as carrier gas $(0.8 \mathrm{~mL} / \mathrm{min}$.). The samples were diluted with hexane 1:100 and were injected into the column $(0.2 \mu \mathrm{l})$ with a split ratio of $40: 1$. The initial oven temperature of the column was $60^{\circ} \mathrm{C}$ and was raised to $220^{\circ} \mathrm{C}$ with a rate of $4^{\circ} \mathrm{C} / \mathrm{min}$ and then kept constant at $220^{\circ} \mathrm{C}$ for $10 \mathrm{~min}$. The injector temperature was at $250^{\circ} \mathrm{C}$. The total analyses duration was $60 \mathrm{~min}$ for each sample. Scanning range for the mass detector was $\mathrm{m} / \mathrm{z} 35$ to 450 and $70 \mathrm{eV}$ electron bombardment ionization was used. The relative percentage of the components was calculated by GC-FID peak areas and components of essential oils were identified by comparison of their mass spectra with 
those in the Adams Library, Wiley GC/MS Library. The results were analyzed by analyses of variance and ranged by Duncan's multiple range tests $[6,7,8,9]$.

\subsection{Isolation of Pathogenic Fungi}

The plant parts having both necrotic and intact tissues were washed under running tap water, dried with paper towels and disinfected in $0.5 \% \mathrm{NaOCl}$ for five minutes. After rinsing with sterile distilled water, small sections about $0.5 \mathrm{~cm}$ of stem pieces having both the intact and necrotic areas dried and plated on the modified selective P5ARPNH-agar (as mg 1-1); pimaricin 5, ampicilline 250, rifampicin 10, PCNB 50, nystatin 50, hymexazole 50) with carrot agar (CA) (40 g thinly grated carrot and $18 \mathrm{~g}$ agar per 1 ) as the basal medium [10, 11]. Pure colonies were obtained by transferring mycelia tips from the cultures growing on the selective medium. Pure cultures were transferred to CA amended with (as $\mu \mathrm{g} \mathrm{ml}^{-1}$ ); $\beta$-sitosterol 30, thiamine hydrochloride 1 and tryptophan 20 to stimulate oospore and sporangia production [12]. Cultures were incubated in the dark at $20 \pm 1^{\circ} \mathrm{C}$ and examined within 2-8 days. Petri plates were incubated at $20 \pm 1^{\circ} \mathrm{C}$ for 3-5 days in the dark [13].

\section{RESULTS and DISCUSSIONS}

\subsection{Biomass and Yield Characteristics}

This research was carried out from a three-years old common sage (Salvia officinalis L.) plantation established in the experimental field of CRIFIC (Central Research Institute for Field Crops), Yenimahalle, Ankara. Two harvests were evaluated from successive two years, on July $10^{\text {th }} 2015$ and July $7^{\text {th }} 2016$. The plants were harvested at the early flowering stage in the recommended period when the essential oil ratio was the highest amount. And the mean yields and quality parameters of the two harvests, minimum and maximum values, coefficient of variation (CV), F value, Least Significant Difference (LSD) were recorded as; plant height (cm/per plant), number of shoots, horizontal and vertical canopy widths $(\mathrm{cm})$, fresh herb yield (g/per plant), dry herb yield (g/per plant), dry leaf yield (g/per plant), leaf ratio (\%) and essential oil ratio $(\%)$ in Table1.

Table1. The mean plant height ( $\mathrm{cm} /$ per plant), number of shoot and both canopy widths ( $\mathrm{cm} /$ per plant), fresh herb yield (g/per plant), fresh leaf yield (g/per plant), dry herb yield (g/per plant), dry leaf yield (g/per plant), leaf ratio (\%) and essential oil ratio (\%) of Salvia officinalis L. harvested on July $10^{\text {th }} 2015$ and July $7^{\text {th }} 2016$.

\begin{tabular}{|c|c|c|c|c|c|c|c|c|c|}
\hline & $\begin{array}{l}\text { Plant } \\
\text { Height }\end{array}$ & $\begin{array}{c}\text { Canopy } \\
\text { width }\end{array}$ & $\begin{array}{c}\text { Canopy } \\
\text { width } \\
\left(90^{\circ} \mathrm{C}\right)\end{array}$ & $\begin{array}{c}\text { Fresh } \\
\text { herb yield }\end{array}$ & $\begin{array}{c}\text { Fresh leaf } \\
\text { yield }\end{array}$ & $\begin{array}{c}\text { Dry herb } \\
\text { yield }\end{array}$ & $\begin{array}{c}\text { Dry leaf } \\
\text { yield }\end{array}$ & Leaf ratio & $\begin{array}{c}\text { Essential } \\
\text { Oil ratio }\end{array}$ \\
\hline Mean & 74.6 & 55.4 & 53.4 & 300.4 & 205.7 & 87.7 & 42.0 & 68.8 & 1.70 \\
\hline Min & 50.3 & 36.0 & 28.2 & 90.50 & 52.9 & 15.6 & 7.9 & 59.7 & 0.97 \\
\hline Max & 97.5 & 95.0 & 77.4 & 718.7 & 488.2 & 185.5 & 79.1 & 75.5 & 2.23 \\
\hline $\mathrm{CV}$ & 7.3 & 21.6 & 6.1 & 13.9 & 16.9 & 16.6 & 13.9 & 4.23 & 7.68 \\
\hline $\mathrm{F}$ & $*$ & $*$ & $* *$ & $* *$ & $* *$ & $* *$ & $* *$ & $* *$ & $* *$ \\
\hline LSD & 9.3 & 23.9 & 5.3 & 89.4 & 84.8 & 34.7 & 29.7 & 5.92 & 0.27 \\
\hline
\end{tabular}

$*: 1 \%, * *: 5 \%$ statistically significant

All the main yield parameters and essential oil ratios were found statistically significant at the level of 0.01 and 0.05 . The plant height was ranged $50.3 \mathrm{~cm}$ to $97.5 \mathrm{~cm}$. The canopy width was changed between $36.0-95.0 \mathrm{~cm}$ and $28.2-77.4 \mathrm{~cm}$, vertically. The fresh herb yield was recorded around 90.50 to $718.7 \mathrm{~g}$ per plant while dry herb yield was ranged 15.6 to 185.5 g per plant. Fresh leaf yield was found between $52.9-488.2 \mathrm{~g}$ while the dry leaf yield was changed between 7.9-79.1 g per plant. The mean essential oil ratio of the lines was $1.70 \%$ while it was asking more than $1.5 \%$ in according to European Pharmacopeia [14]. 
Sage and sage essential oil (which can be up to 50\% thujone) are on the list of Food and Drug Administration and generally recognized as safe (GRAS) substances [15]. The European Medicines Agency (EMA) has recently implemented an acceptable daily intake (ADI) of 5.0 $\mathrm{mg} /$ person for a maximum duration of use of 2 weeks in their Salvia officinalis monograph [16].

\subsubsection{Fresh Herb Yield}

As shown in Figure 1. the prominent 15 lines were yielded more than means of experiment and more or close than the means of control. The highest fresh herb yield was recorded at line 17 by 718.7 g per plant and this was followed by line 12,1 and 2 with 440.8 , 439.9 and $433.1 \mathrm{~g} /$ per plant, respectively. The mean fresh herb yield of CV Regula was recorded at $708.4 \mathrm{~g} /$ per plant which was showing the best performance regarding controls from 3 replicate.

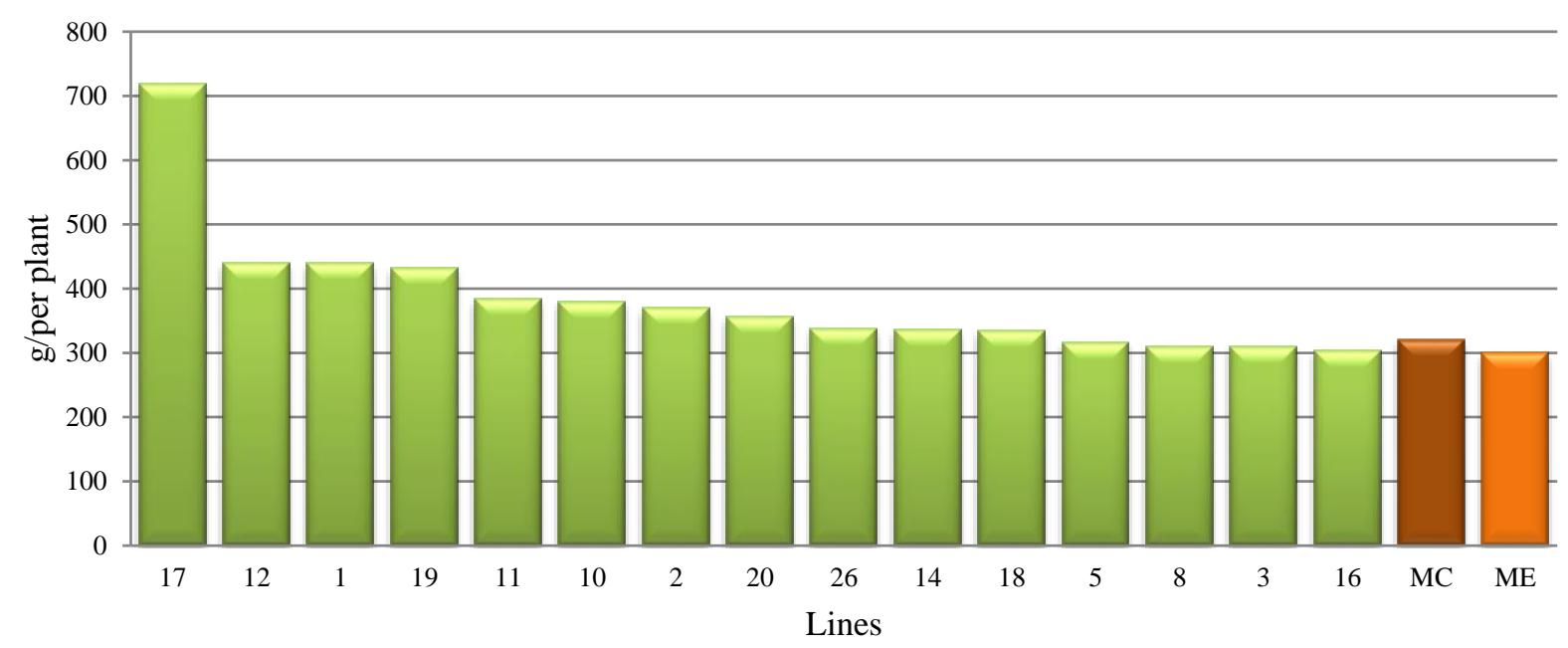

Figure1. The fresh herb yield (g/per plant) of the prominent 15 lines versus the means of control (ME) and the means of experiment (ME). LSD (P 0.01)=89.4

\subsubsection{Dry Herb Yield}

Depending on the fresh herb yield parameters, the highest mean dry herb yield was recorded at line 17 by $185.5 \mathrm{~g}$ line 12,1 and 19 followed it by136.9, 134.5 and $121.5 \mathrm{~g}$ per plant respectively.

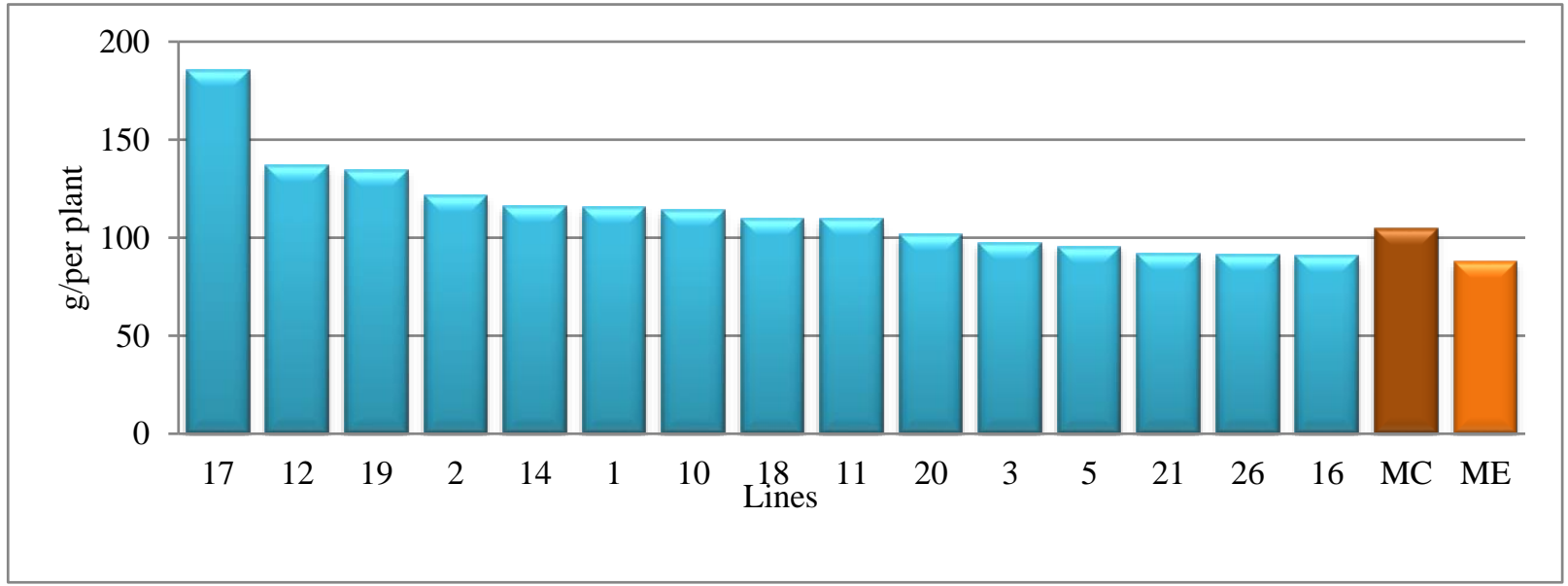

Figure 2. The dry herb yield (g/per plant) of the prominent 15 lines versus the means of control (MC) and means of experiment (ME). LSD (0.01) $=34.7$. 


\subsubsection{Fresh Leaf Yield}

The highest fresh leaf yield was recorded at line 17 by $484.2 \mathrm{~g} /$ per plant, and line 1,12 and 19 were followed it by 330.6, 302.1 and 279.2 g per plant respectively (Figure3). The prominent 15 lines were exceeded the means of experiment regarding their fresh leaf yield which is considered as an important indicator of biomass production.

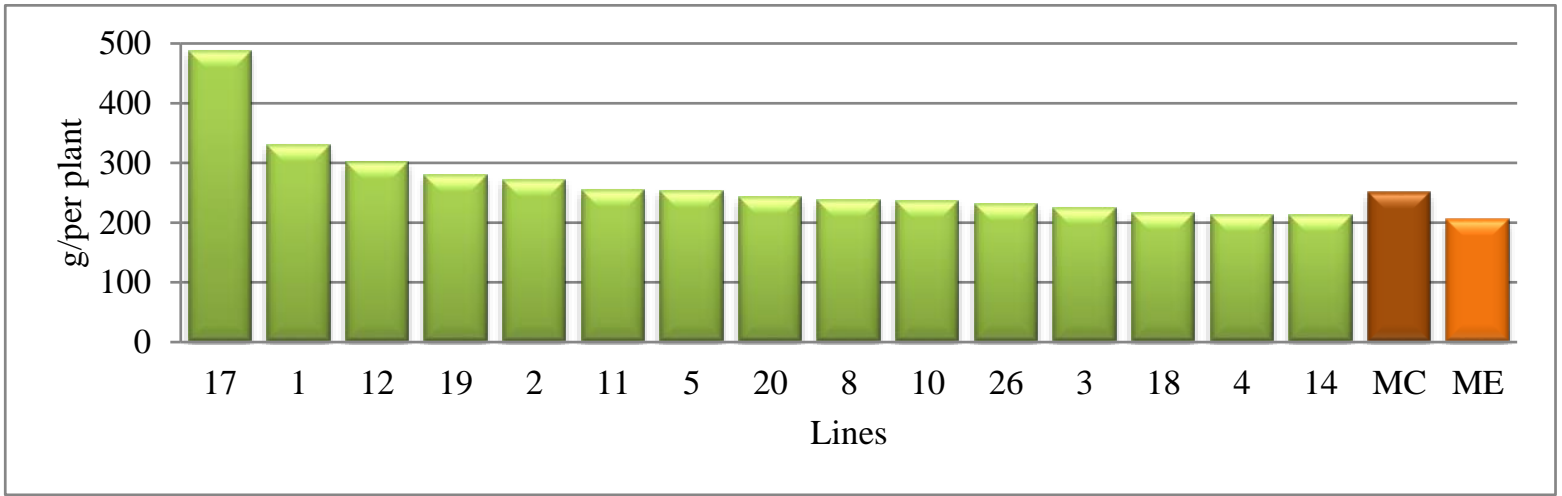

Figure 3. The fresh leaf yield (g/per plant) of the prominent 15 lines versus the means of control (MC) and the means of experiment (ME). LSD $(0.01)=84.8$

\subsubsection{Dry Leaf Yield}

Depending on the fresh leaf yield the highest dry leaf yield was recorded at line 17 by $79.1 \mathrm{~g} /$ per plant, and line 1, 5 and 11 were followed it by 73.0, 71.8 and $70.2 \mathrm{~g}$ per plant respectively (Figure 4). Seven lines had more than $50 \mathrm{~g}$ dry leaf yield which exceeded both the means of control and means of experiment. While the demand to the stripped dry leaves in exportation has great value, the dry leaf yield of the lines was desired at line selection in common sage.

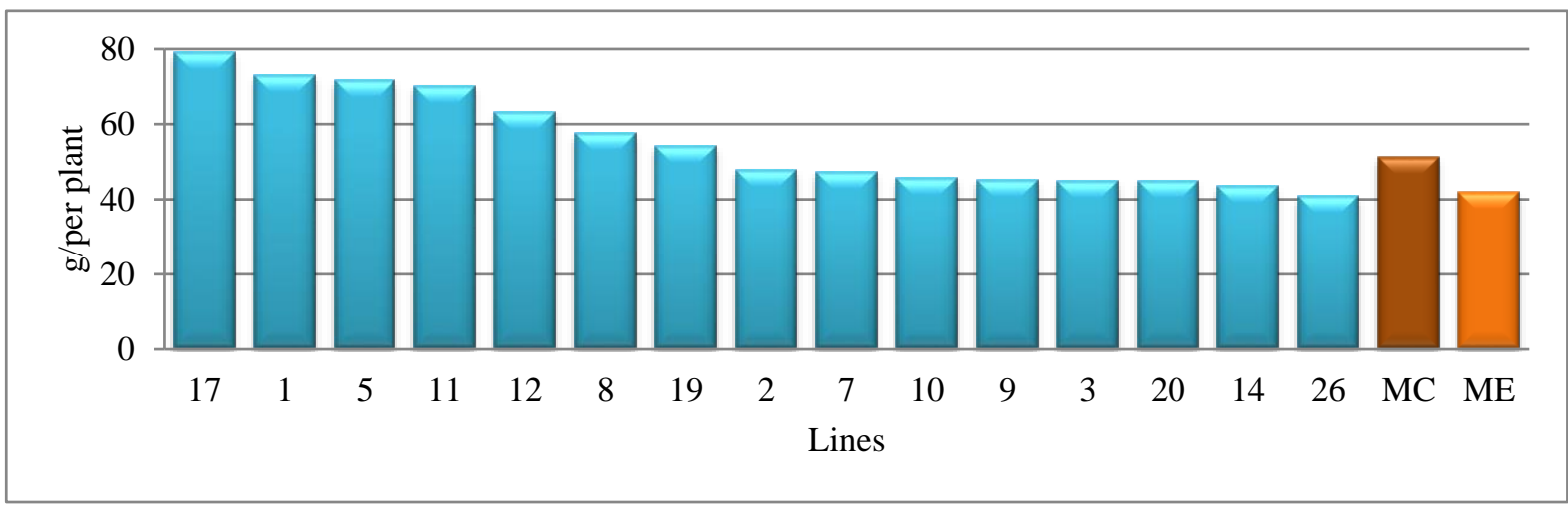

Figure 4. The dry leaf yield (g/per plant) of the prominent 15 lines versus the means of control (MC) and means of experiment (ME). LSD $(0.01)=29.7$

\subsection{Essential Oil Characteristics}

\subsubsection{Essential Oil Yield}

The mean essential oil of the lines was found $1.70 \%$ and $1.82 \%$ for the controls. Line 30 has the highest amount of essential oil ratio by $2.24 \%$ and this was followed by line 1,24 and 6; by $2.20 \%, 2.07 \%$ and $2.05 \%$, respectively. Seven lines had $2 \%$ and more essential oil and 15 lines recorded more than $1.5 \%$ essential oil ratio compared to the means of control $(1.82 \%)$ and the means of experiment $(1.70 \%)$. Line 17 which has the highest yield parameters had $1.49 \%$ essential oil content which was determined below the means of control and the means of experimental (Figure 5). 


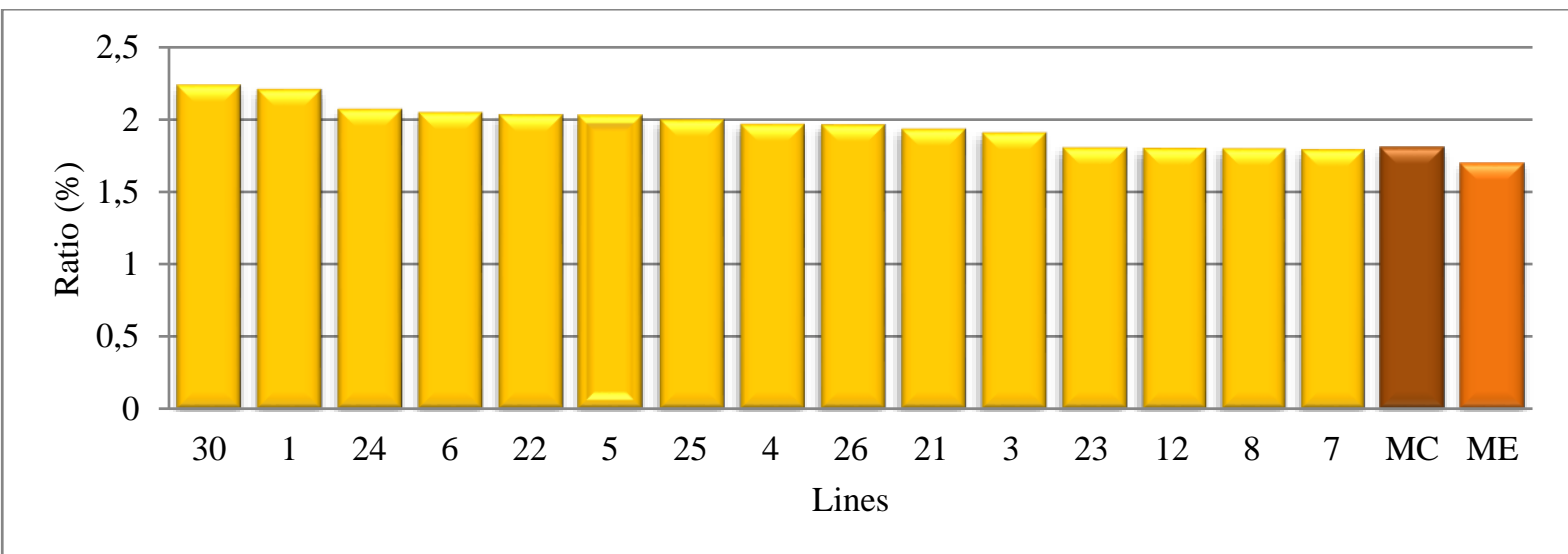

Figure 5. The essential oil ratio (\%) of the prominent 15 lines versus the means of control (MC) and the means of experiment $(\mathrm{ME})$. $\operatorname{LSD}(0.01)=0.27$

This amounts are found parallel, regarding previous findings; by $1.1 \%$ from dried $S$. officinalis ssp. major leaves, harvested while the plants were blooming [17] and another ranging 1.7 to $2.2 \%$ [18].

\subsubsection{Essential Oil Composition}

The main essential oil components of the common sage lines were determined as; $\alpha$ thujone, $\beta$-thujone, borneol, 1.8 cineol, camphor, $\alpha$-pinene, camphene, viridiflorol, $\beta$-pinene, $\alpha$ humulene, manool, limonene and cis-salvene. Line 23 was recorded the less $\alpha$-thujone content by $9.8 \%$ and this was followed by line 9 and 17 by; $12.5 \%$ and $13.7 \%$, respectively. $\alpha$-thujone and $\beta$-thujone are the undesirable two components in common sage essential oil which $\beta$ thujone was considered much toxic. For example; FDA (Food Drug Administration) asked less than $30 \%$ thujone for the use common of herbal drug and less than $50 \%$ as food. The hybrid lines were generated wide variability regarding their essential oil compositions as shown in Figure 6.

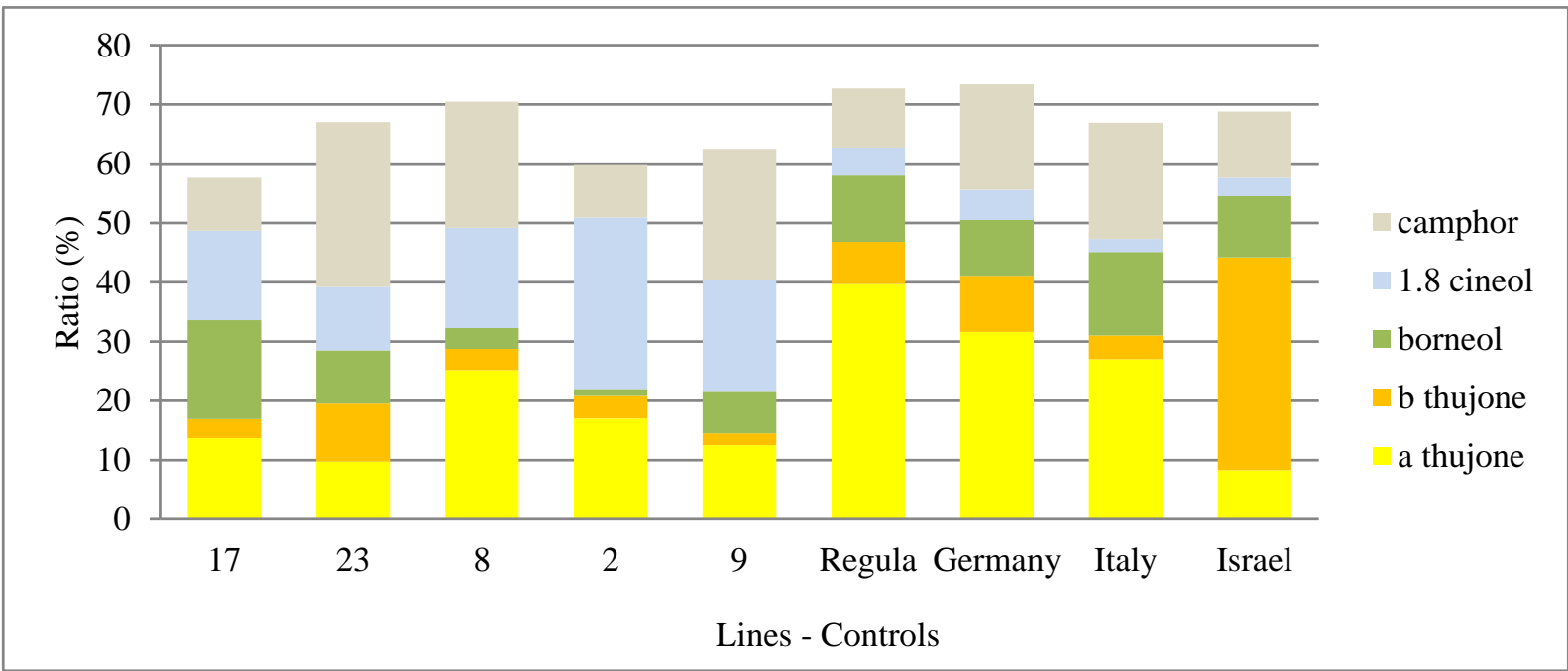

Figure 6. The main essential oil components ( $\alpha$-thujone, $\beta$-thujone, borneol, 1.8 cineol and camphor) of the selected lines $(17,23,8,2$ and 9) and the controls (CV Regula-Swiss, the population Germany, Italy USDA IP: 4620659 and Israel) $\%$.

The major EO of the lines were isolated as $\alpha$-thujone (8.32-42.46\%), $\beta$-thujone(2.02$21.39 \%), 1.8$ cineol (4.66-29.34\%), borneol (0.91-16.73\%) and camphor (4.22-30.77\%). The other components were identified as; $\alpha$-humulene (1.94-7.60\%), viridiflorol $(3.56-21.91 \%)$, borneol (0.91-16.73\%), camphene (0.76-9.73\%), $\beta$-pinene $(1.25-14.26 \%), \beta$-myrcene $(0.45$ - 
$1.89 \%)$, limonene (0.89-2.25\%), manool (0.70-7.29\%) and cis-salvene (0.35-1.40\%) as shown in Figure 6.

Some constituents mentioned in other handbooks are borneol, bornyl acetate, isorosmanol [19], linalyl acetate, chlorogenic-, ellagic-, ferulic- and gallic phenolic acids [20], linalool, $\alpha-$ pinene, camphene, limonene [21]. The principal components were determined as monoterpenoids such as $\alpha$-thujone (10-60\%), $\beta$-thujone (4-36\%), camphor (5-20\%) and 1,8cineole $(2-15 \%)$, together with sesquiterpenes such as $\alpha$-humulene, $\beta$-caryophyllene and viridiflorol [22-24] from previous studies.

\subsection{Pathogenic Fungi}

The symptoms observed from the samples were typical of the descriptions given by $[25,26]$. Identification of our isolates based upon the formation of hyphal swellings, morphology of sporangia and oospores, and growth at cardinal temperatures was easily made. The identification of the isolate was confirmed by sequence analysis of the ribosomal DNA internal transcribed spacer region using primers ITS1 and ITS4. The ITS sequence matched 99\% to many of the isolates of P. cryptogea strains deposited in Gene Bank (Accessions; KC695697 and KR011187.1) [13].

\section{Acknowledgement}

The authors would like to thank to Ministry of Turkish Food, Agriculture and Livestock, General Directorate of Agricultural Research and Policy, for founding this Project financially.

\section{Conflict of Interests}

Authors declare that there is no conflict of interests.

\section{CONCLUSION}

Common sage (Salvia officinalis L.) has a wide adaptability and non-selective climatic requirements, provides their cultivars two or more harvests in a plantation period, having high biomass yield, in Central Anatolian climatic conditions. In the present research, spontaneous hybrid line 17 was shown the highest fresh and dry herb yield by 718.7 and $185.5 \mathrm{~g}$ per/plant compared to the controls and the means of the experiments. The highest fresh leaf and dry leaf yields were also belongs to line 17 by $482.2 \mathrm{~g}$ per/plant and $79.1 \mathrm{~g}$ per/plant, respectively. Line $12,1,19$ and 5 were found promising in biomass production. 17 was found also one of the lowest $\alpha$-thujone content line, having the mean of $13.7 \% \alpha$-thujone, in the successive two years. Line 30 had the highest essential oil ratio by $2.24 \%$ and this was followed by the lines 1, 2, 4, 6, 22 and 5, having more than 2\% essential oil. Phytophtora cryptogea was identified as pathogenic fungi causing root rots on the sage plantation, proven by genetic characterization.

\section{REFERENCES}

[1]. Madaus, G. (1938). Textbook of Biological remedies. Leipzig: Georg Thieme Verlag, 1, 12.

[2]. Hanson, A.A., Barns, D.K., Hill, R.R., (1988). Alfalfa and Alfalfa Improvement. Printed in the 677 South Segoe Road, Madison, WI 53711 USA, 1083, 784-785.

[3]. Tannous, P., Juliani, R., Wang, M., \& Simon, J. (2004). Water balance in hydrosol production via steam distillation: case study using lavandin (Lavandula $\mathrm{x}$ intermedia). New Use Agricultural and Natural Plant Products and ASNAPP Program. The State University of New Jersey: New Jersey. 
[4]. Baydar, H., \& Kineci, S. (2009). Scent composition of essential oil, concrete, absolute and hydrosol from lavandin (Lavandula x intermedia Emeric ex Loisel.). Journal of Essential Oil Bearing Plants, 12(2), 131-136.

[5]. Boutekedjiret, C., Belabbes, R., Bentahar, F., Bessiere, J. M., \& Rezzoug, S. A. (2004). Isolation of rosemary oils by different processes. Journal of Essential Oil Research, 16(3), 195-199.

[6]. Adams, R.P. (2007). Identification of essential oil components by gas chromatography/mass spectroscopy. 4th Ed. Allured Publ. Corp. Carol Stream, IL

[7]. Davies, N. W. (1990). Gas chromatographic retention indices of monoterpenes and sesquiterpenes on methyl silicon and Carbowax 20M phases. Journal of Chromatography A, 503, 1-24.

[8]. Jennings, W. (2012). Qualitative analysis of flavor and fragrance volatiles by glass capillary gas chromatography. Elsevier.

[9]. Düzgüneş, O., Kesici, T., Kavuncu, O. ve Gürbüz, F. (1987). Statistical Methods in Research. Journal of Ankara University Agricultural Faculty. 1021, P.381. Ankara

[10]. Jung, T., Blaschke, H., \& Neumann, P. (1996). Isolation, identification and pathogenicity of Phytophthora species from declining oak stands. Forest Pathology, 26(5), 253-272.

[11]. Akı1l1, S., Serçe, Ç. U., \& Maden, S. (2012). Involvement of Phytophthora spp. in chestnut decline in the Black Sea region of Turkey. Forest Pathology, 42(5), 377-386.

[12]. Wilcox, W. F., \& Ellis, M. A. (1989). Phytophthora root and crown rots of peach trees in the eastern Great Lakes region. Plant disease, 73(10), 794-798.

[13]. Çakır, E., Bahtiyarca Bağdat, R., Katırcıoglu, Y.Z., Maden, S. (2017). Occurrence of root rot caused by Phytophthora cryptogea on common sage (Salvia officinalis) in Turkey. Journal of Agricultural Science and Tecnology A. 7 (2017) 401-406. doi: 10.17265/21616256/2017.06.005.

[14]. Anonymous, (2012). http://bhma.info/wpcontent/uploads/2012/12/SalviaMonograph1.pdf

[15]. Anonymous, (2006). Substances generally recognized as safe. Food and Drug Administration (2003). Retrieved Oct 28, 2006.

[16]. Anonymous, (2009). EMA. Community herbal monograph on Salvia officinalis L., folium. London, UK: European Medicines Agency; 2009.

[17]. Perry, N. B., Anderson, R. E., Brennan, N. J., Douglas, M. H., Heaney, A. J., McGimpsey, J. A., \& Smallfield, B. M. (1999). Essential oils from Dalmatian sage (Salvia officinalis L.): variations among individuals, plant parts, seasons, and sites. Journal of Agricultural and Food Chemistry, 47(5), 2048-2054.

[18]. Oelschlägel, S., Quaas, S., \& Speer, K. (2012). The essential oil content and composition of selected Salvia species, sage teas, and sage drops. Journal of Food Science and Engineering, 2(8), 427.

[19]. Wichtl, M. (Ed.). (2004). Herbal drugs and phytopharmaceuticals: a handbook for practice on a scientific basis. CRC press.

[20]. Newall, C. A., Anderson, L. A., \& Phillipson, J. D. (1996). Herbal medicines. A guide for health-care professionals. The pharmaceutical press.

[21]. Blumental, M., Goldberg, A., \& Brinckmann, J. (2000). Herbal medicine. Expanded Commission Monographs. Austin, TX: American Botanical Council.

[22]. Lawrence, M. B. (1998). Progress in Essential Oils-Sage Oil, Fennel Oil and Cardamom Oil. Perfumer and Flavorist, 23(2), 47-57. 
[23]. Lawrence, B. M. (1992). Chemical components of Labiatae oils and their exploitation. Advances in Labiatae science, 399-436.

[24]. Pitarević, I., Kuftinec, J., Blažević, N., \& Kuštrak, D. (1984). Seasonal variation of essential oil yield and composition of dalmatian sage, Salvia officinalis. Journal of natural products, 47(3), 409-412.

[25]. Garibaldi, A., Bertetti, D., Pensa, P., Ortu, G., \& Gullino, M. L. (2015). Phytophthora cryptoea on Common Sage (Salvia officinalis L.) in Italy. Plant Disease, 99(1), 161-161.

[26]. Koike, S. T., Henderson, D. M., MacDonald, J. D., \& Ali-Shtayeh, M. S. (1997). Phytophthora Root and Crown Rot of Sage Caused by Phytophthora cryptogea in California. Plant Disease, 81(8), 959-959. 